\title{
Effectiveness of Transformational Leadership among Different Cultures
}

\author{
Mersid Poturak ${ }^{1}$ \& Ensar Mekić ${ }^{2}$ \& Nereida Hadžiahmetović ${ }^{3} \&$ Taylan Budur ${ }^{4}$ \\ ${ }^{1,2 \& 3}$ Faculty of Economics and Social Sciences, International Burch University, Sarajevo, Bosnia and \\ Herzegovina \\ ${ }^{4}$ Business and Management Department, Faculty of Administrative Science and Economic, Tishk \\ International University, Sulaymaniyah, Iraq \\ Correspondence: Mersid Poturak, International Burch University, Sarajevo, Bosnia and Herzegovina. \\ Email: mersid.poturak@ibu.edu.ba
}

Doi: 10.23918/ijsses.v7i3p119

\begin{abstract}
Culture is shared assumptions, beliefs, attitudes, or beliefs that helps individuals or groups to respond various actions or events that they face in daily life. Besides, leadership is art of influencing others to achieve desired objectives in organizations. On one hand, the growing body of the literature argues the effectiveness of the transformational leadership. On the other hand, cultural background has different impacts on this leadership style. In this respect, current paper aims to point out some consequences of transformational leadership in various cultures. As a result, it has been observed that because of its charismatic and simulative characteristics, these leaders are more effective on developed countries and innovative characteristics rather than group oriented and depressed cultures.
\end{abstract}

Keywords: Transformational Leadership, Cultural Differences, Hofstede Cultural Dimensions, Employee Performance, Innovative Behaviour, Kurdistan, Iraq

\section{Introduction}

Through globalization and various developments, the world has been a small country that people can reach each other faster and communicate easily. In this respect, not only individuals even organizations have passed over the borders to find new opportunities in other countries. Accordingly, management science or art must find different ways to increase internal and external productivity of their firms to survive in the long term. Especially, leaders in the companies should have appropriate skills and capabilities to carry their organization correctly in the future.

The goal of a leader is to reach organizational objectives with and through people (Jones, 2013). Besides, other departments such as HRM, aims to increase the efficiency of the factors that contribute to operational processes to help administrators achieve objectives (Altun, 2017; Demir \& Bulut, 2018; Kamal \& Shawkat, 2020). Otherwise, the misuse of resources will not be avoided, which means that productivity cannot be accomplished and a decline in the business will continue, respectively. (Mohammed et al., 2020; Zaim et al., 2020).

Further, leadership is one of the important promoters of the organizational effectiveness (Budur, 2018). Previous studies noted that leadership has strong relationship with organizational culture, employee performance and satisfaction that in turn positively associated with organizational success and competitive advantages in the long term (Ali \& Yildiz, 2020; Bass \& Avolio, 1994; Budur \& Poturak, 2020). 
In this respect, scholars noted that transformational leadership is one of the most influential leadership styles on the positive employee- and organizational outcomes (Bass, 1985; Demir \& Budur, 2019). Because of its visionary, charismatic and supportive characteristics transformational leaders leverage employee engagement, commitment, and performance (Abdulla et al., 2020; Torlak \& Kuzey, 2019).

To date, researchers have argued the distinguishing features of these leaders as they draw followers of dedication and affiliation with leaders and organizations by empowering and motivating them to act beyond the requirements (Budur \& Demir, 2019; Top et al., 2020). A further factor was described in the literature as their bidirectional communication of moral and motivational behaviours that benefit leaders and followers together (Bass, 1985). Accordingly, through appropriate communication and interaction with followers they can positively affect internal effectiveness (Budur \& Porturak, 2021), which is employee performance, commitment, and satisfaction and in turn leverage the customer relationship and satisfaction respectively (Al-Abrrow, 2014; Boerner et al., 2007; Tajeddini, 2010).

Consequently, some leadership researchers noted that TL has positive effects in different cultures universally (Bass, 1985; Bass \& Avolio, 1994; Den Hartog et al., 1999), while many scholars noted the importance of culture that consequences of leaders varies based on the geographies (Budur \& Demir, 2019; House et al., 1997). Accordingly, current paper is going to search for mainly if the leadership behaviours have always the same effects among the different cultures; and does the transformational leadership have always positive impact on followers in the various environments?

\section{Theoretical Background}

\subsection{Transformational Leadership}

Transformational leaders provide a consistent encouragement and motivation for quality communication between leader and followers for further developments in the company (Bass, 1985; AL-Abrrow, 2018). Burns (1978) conceptualization of transformational and transactional leadership styles have been improved and empirically evaluated by Bass $(1985,2002)$ based on the personal and organizational level. Accordingly, these leaders have four main characteristics to attract and affect followers in the workplace (Bass \& Avolio, 1994).

Following this further; idealized influence refers to affect followers with charisma (being role model) to act beyond expectations (Dionne et al., 2004). Further, idealized influence covers leader's emotional connection with subordinates that leaders attract others through his visionary and ethical behaviours (Linge $\&$ Sikalieh, 2019). The reason why the charismatic leaders (idealized influence) have strong impact on followers is that these leaders are strongly related with the objectives of the company and they are engaged with their actions (Tajeddini \& Mueller, 2012).

Inspirational motivation involves the supportive behaviours to increase follower's motivation as; being optimistic about the future and articulating the vision of the organization among subordinates. Hence, considering and drawing a clear future orientation for the staff are some of the motivational effects of inspirational motivation dimension of transformational leaders (Bass \& Avolio, 1994).

Intellectual stimulation comprises leader's empowerment to be innovative for new ideas or problems. Besides, that dimension encourages intelligence in the workplace for the productivity that establishes 
opportunities for promotion (Bayram \& Dinc, 2015). Further, scholars noted that the aim of these supportive behaviours of TL is to increase subordinate's awareness about problems, beliefs, and values within the organization (Budur \& Poturak, 2020; Yildiz \& Amin, 2020).

And finally, individual consideration refers to mentoring followers for individual career development and achievements (Faeq, 2020; Zardasht et al., 2020). Further, considering and listening staff individually and helping them to find and improve their weak points and in this concept providing related trainings are some of the examples of this dimension (Bass, 1985; Kanval et al., 2019).

\subsection{Importance of Culture on Employee Behaviours}

Culture is an important factor that shapes employees' and customers' behaviours in certain field or country. Culture is defined by Hofstede (1980) as "the collective programming of the mind which distinguishes the members of one human group from another". Similarly, Schein (1986) has defined culture as "a pattern of shared basic assumptions that was learned by a group as it solved its problems of external adaptation and internal integration, that has worked well enough to be considered valid and, therefore, to be taught to new members as the correct way to perceive, think, and feel in relation to those problems". Culture represent different characteristics as religion, language, tradition, norms, or systems and generally it is different from one place to another (Hofstede, 1980). Scholars argued the cultural differences and their effects on the effectiveness of marketing and communication to increase market share (Welch \& Jackson, 2007; Mead \& Jones, 2017). In this concept, by defining marketing strategies practitioners should be aware of how cultural differences influential on the personal or societal preferences and behaviours.

One of the widest cultural study in the literature is done by Hofstede and noted the cultural differences in the workplace as employee value perception, managers behaviour, consumer behaviour, and marketing related activities of organizations and customers responses according to their culture (Hofstede, 1986, 2003, 2009, 2011; Hofstede \& Bond, 1984; Hassan, 2015ab). This study has involved and observed more than 100.000 IBM employees' behaviours in 40 countries between 1967 and 1973 (Hofstede, 2009). As a result, Hofstede summarized five main dimensions to explain cultural differences among countries. These dimensions are Individualism, Masculinity, Power Distance, Uncertainty Avoidance, and Long-Term Short-term Orientation (Hofstede, 1998; Hofstede \& Fink, 2007). Besides Hofstede, some researchers have used different classifications to investigate cultural differences in society like; Sojka and Tansuhaj (1995) investigated consumer behaviours in 20 years; Lenartowicz and Roth, (1999) examined the cultural effects on business life (Soares et al., 2007). But according to our reviews of literature the widely used one to evaluate cultural effects on business is Hofstede's classification, which is going to be explained here briefly. The dimensions of Hofstede are:

Individualism-collectivism: This dimension gives information about the characteristics of the individual behaviours. Hofstede (2011) noted that individuals have two types of sources in their behaviours, which are individual and group oriented. Individual oriented personalities are tended to behave and define their future alone, they are explicit, direct and like risk taking. And group oriented or affected personalities implicit and indirect (Hassan, 2015a). Further Hofstede stated that salespeople contact, communication and organizational advertisements or marketing strategies should be more influential in individualistic cultures rather than collectivistic (Brewer \& Venaik, 2011). 
Uncertainty avoidance: Uncertainty is the people's hesitation or avoidance from unclear or ambitious events or possibilities (Hofstede, 2011). Soares et al. (2007) noted this dimension requires clarification of rules, circumstances, or threads that they face. Further, this dimension investigates stress, anxiety, tendency to reading, traveling or sport, and having personal computer (Hofstede, 2012; Hassan, 2015b). Consequently, Hofstede aimed to measure the welfare or comfortable level of the society and noted that low level of uncertainty avoidance cultures has fewer rules (do not like rules), less stress, more tendency to change current job and have risk for entrepreneurial actions, while high level of uncertainty avoidant countries has more structures, rules, hectic, do not like to change job and stress in the daily life (Hofstede, 2009; Wennekers et al., 2007).

Power distance: This dimension refers to the consequences of power differences of inequality in the family, organizations, or society. Hassan (2015) noted this dimension as individual's appearance, communication, behaviours and attitudes in the private or public environment. In line with this, Craig, and Douglas (2011) noted that this dimension explains the effects of power or inequality on the individual expectations, future decisions, objectives and personalities in a society.

Masculinity-femininity: It refers to the dominant values and responsibilities between genders. Hassan (2015) stated the tendency to luxury, shopping, internet usage, and brand preferences are examples for this dimension. Further, Hofstede (2011) noted while competition, desire for achievement, increasing performance, and controlling one's environment are some of the indicators of masculine cultures; equality, modest, helping others, sharing responsibility at home and outside, and tendency for shopping are some indicators of feminine societies.

Long-term orientation: This dimension refers to future orientation of the society by their persistence and thrift, while short term-oriented cultures tended for past and current fulfilments (Hassan, 2015). Hofstede noted that long term orientated societies invest their daily time for their future achievement, whereas short term-oriented people deal with routines and traditions (Hofstede, 2011).

Results of Hofstede's Cultural Study about Iraq

Hassan et al. (2016) noted the following results of Hofstede's cultural index; high level of "Power distance" which represent the inequality among the social levels. As Hama (2015) mentioned that because of the lack of politic and economic unsustainability, several wars in the region and long lasted dictator regime negatively affected developments in the region. Following this further, governments could not provide equal services for the public as well (Hama, 2015; 2019). However, in contrast to Hofstede index Rarick et al. (2014) and Hassan (2015) found that Kurds in Iraq have lower level of "Power Distance". The reason for this difference noted by Hassan (2015) as the education and age. But as Hama (2015) mentioned the region has more democratic government, better possibilities in social life and economic power in compare to history of the country.

By the Collectivism Hassan (2015) and Hofstede are in the same line that Iraqi people and Kurds are familiar for teamwork and sacrifice their objectives easily for the profit of the society. The reason for that explained by Hofstede and Hassan as; that families in the region have more members and formal legislation system based on the traditions and tribes of the country, which educate people to save their own values and societal virtues. 
According to Rarick et al. (2014) findings, while Iraqi people masculine oriented, Kurds are slightly feminine oriented. Further, by uncertainty avoidance Arab cultures are more avoidant against uncertainty, while Kurds have less sensibility to uncertainty. The reason for that revealed by Hassan (2015) that Kurds have mountainous background that means Kurds like standard rules, they have no resistance for change, and open for new things. Besides, Hassan noted that majority of Kurds working in public sector and have standard salary payments monthly that provide them a minimally standard level of life.

Finally, Hofstede and Rarick et al. (2014) stated that Arabs and Kurds are short term oriented, while Hassan (2015) revealed Kurds as long term oriented. As a result, like every theory Hofstede's cultural dimensions have limitations and weaknesses as well. The reason that we put a small summary of this theory is that we have found some evidences to support our results in line with a few studies that used this model in the literature as well.

\subsection{Research Findings on the Effectiveness of the TL in Different Cultures}

Culture-specific approach involves the differences among the cultures that leaders should have variety of skills and abilities to be effective in several geographies (Ergeneli et al., 2007). To date, scholars have claimed that some societies are relatively egalitarian, while others have distinct concepts of governance or social ties (Hofstede, 2009).

According to Bass (1985) TL has positive impacts on employee satisfaction and performance. Similarly, Nanjundeswaraswamy and Swamy (2014) indicated TL is more effective than other leadership styles on the performance and overall satisfaction. Kuchinke (1999) examined the TL perception of US and German employees in telecommunication sector whereas German employees have lower acceptance of TL, US employees have positive perception about the effectiveness of the TL.

Shao and Weber (2006) explored the cultural dimensions and TL in China. They noted China has high power distance and high uncertainty avoidance, which refers to collectivism and centralized authority are negatively related to TL. Ergeneli et al. (2007) investigated TL impact in Turkey based on Hofstede's dimensions and noted that some of the aspects of TL are culture-specific, while some aspects are common in different cultures. Accordingly, inspirational motivation and modelling of TL were negatively related to uncertainty avoidance, while encouragement was positively correlated with power distance in Turkey.

Mujkic et al. (2014) have compared TL impact in two cultures of Germany and Bosnia Herzegovina. They have observed the strongest character of TL was individual consideration and then intellectual stimulation was more significant in Germany. Consequently, they have noted that TL was more influential in Germany in compare to Bosnian culture (Muikic et al., 2014). On the other hand, Bayram and Dinç (2015) have studied the TL impact on employees of private universities in Bosnia and Herzegovina in this respect. And they have found that idealized influence and inspirational motivation have significant impact on employee job satisfaction, while intellectual stimulation and individual consideration did not have any significant impact respectively (Bayram \& Dinc, 2015).

Anwar and Balcioglu (2016) studied the TL impact on construction employees in Erbil and found that idealized influence of TL has strongest impact on the effectiveness of the subordinates. Another finding of the study was the intellectual stimulation characteristic of TL has the weakest impact on employees, 
which is in line with Hofstede's cultural results. Hofstede and Hassan (2015) noted that Kurdish people are group oriented and tended to follow their leaders instead of being innovative. Further, Budur and Poturak $(2020 ; 2021)$ investigated TL impact on employee's citizenship behaviours and performance in Sulaymaniyah and Erbil within a sample of 420 from various SMEs. They noted that inspirational motivation and individual consideration of TL has stronger impact on residential employees, while intellectual stimulation has not significant impact. These results are in the same line with Hofstede (2009) and Anwar and Balcioglu (2016).

Furthermore, Ali et al. (2020), Budur and Demir (2019), and Demir and Budur (2019) have investigated the leadership impacts on employees socially responsible behaviours in Sulaymaniyah city of Iraq. They have found that Ethical Leadership is more influential on employee's social responsibilities in compare to TL. 
Table 1: Research findings related to TL in different countries

\begin{tabular}{|c|c|c|c|}
\hline Year & Country & Aim of the study & Findings \\
\hline Dunn (1999) & $\begin{array}{l}\text { USA and } \\
\text { Israel }\end{array}$ & $\begin{array}{l}\text { TL impact on US } \\
\text { and Israeli } \\
\text { employees. }\end{array}$ & $\begin{array}{l}\text { There are no significant } \\
\text { differences. }\end{array}$ \\
\hline Kuchinke (1999) & $\begin{array}{l}\text { USA and } \\
\text { Germany }\end{array}$ & $\begin{array}{l}\text { TL perception of } \\
\text { managers, engineers, } \\
\text { and employees. }\end{array}$ & $\begin{array}{l}\text { US employees have higher } \\
\text { acceptance of TL. }\end{array}$ \\
\hline $\begin{array}{l}\text { Posner and Harder } \\
(2002)\end{array}$ & $\begin{array}{l}\text { USA and } \\
\text { Swiss }\end{array}$ & $\begin{array}{l}\text { TL dimensions in } \\
\text { two cultures. }\end{array}$ & $\begin{array}{l}\text { No difference by modelling and } \\
\text { enabling others. However, } \\
\text { significant differences by } \\
\text { inspiration and encouraging the } \\
\text { hearth. }\end{array}$ \\
\hline $\begin{array}{l}\text { Shahin and Wright } \\
\text { (2004) }\end{array}$ & Egypt & $\begin{array}{l}\text { TL effects on } \\
\text { Banking Sector }\end{array}$ & No significant findings. \\
\hline $\begin{array}{l}\text { Shao and Weber } \\
\text { (2006) }\end{array}$ & China & $\begin{array}{l}\text { TL and cultural } \\
\text { dimensions. }\end{array}$ & $\begin{array}{l}\text { TL is less effective in China in } \\
\text { compare to North America. }\end{array}$ \\
\hline $\begin{array}{l}\text { Mujkic et al., } \\
(2014)\end{array}$ & $\begin{array}{l}\text { Germany } \\
\text { and } \\
\text { Bosnia }\end{array}$ & $\begin{array}{l}\text { TL difference } \\
\text { Germany and Bosnia } \\
\text { Herzegovina. }\end{array}$ & $\begin{array}{l}\text { TL was more influential in } \\
\text { Germany }\end{array}$ \\
\hline $\begin{array}{l}\text { Bayram and Dinc } \\
(2015)\end{array}$ & $\begin{array}{l}\text { Bosnia } \\
\text { and } \\
\text { Herzegov } \\
\text { ina }\end{array}$ & $\begin{array}{l}\text { TL effectiveness in } \\
\text { private universities. }\end{array}$ & $\begin{array}{l}\text { Idealized influence and } \\
\text { inspirational motivation had } \\
\text { significant impact on employee job } \\
\text { satisfaction. }\end{array}$ \\
\hline Mohamed (2016) & Egypt & $\begin{array}{l}\text { TL effects on Hotel } \\
\text { Employees }\end{array}$ & $\begin{array}{l}\text { Promotes employee's innovation } \\
\text { and creativity. }\end{array}$ \\
\hline $\begin{array}{l}\text { Anwar and } \\
\text { Balcioglu (2016) }\end{array}$ & Iraq & $\begin{array}{l}\text { TL impact on } \\
\text { construction } \\
\text { employees in Erbil }\end{array}$ & $\begin{array}{l}\text { Idealized influence had the } \\
\text { strongest impact on the } \\
\text { effectiveness. }\end{array}$ \\
\hline $\begin{array}{l}\text { Ali et al., (2020), } \\
\text { Budur and Demir } \\
\text { (2019), and Demir } \\
\text { and Budur (2019) }\end{array}$ & Iraq & $\begin{array}{l}\text { Leadership } \\
\text { effectiveness on } \\
\text { employees socially } \\
\text { responsibility. }\end{array}$ & $\begin{array}{l}\text { TL is less effective than Ethical } \\
\text { leadership in Kurdistan on } \\
\text { employees' social actions }\end{array}$ \\
\hline
\end{tabular}




\section{Discussion and Conclusion}

The aim of the current paper was to review of the literature to discuss about the various impacts of the transformational leadership in different cultures. In this respect, employee performance and cultural dimensions of power distance and uncertainty avoidance have been mainly conceptualized as the consequences of TL.

Many researchers put forward that TL has significant impacts on individual and organizational performance, as motivating organizational members to act beyond expectations (Bass, 1985; 2002; Boerner et al., 2007; Koran \& Koran, 2017). Because of its widely defined characteristics (4 I's: Idealized influence, Inspirational motivation, Intellectual stimulation, and Individual consideration) transformational leaders should have significant and positive influence on followers. Bass (1985) summarizes those characteristics as.

- Raise collective perception about future orientation and company vision

- Supports followers to act beyond expectations

- Encourage subordinates to solve problems based on their experience and innovative behaviours

- Individually cares with employees' problems for further motivation.

From these points, it could be understood that those leaders who can use 4 I's could be accepted as effective leader that leverage employee and organizational performance (Howell \& Avolio, 1993; Jung et al., 1995). However, culture is an important factor that affect people's behaviours based on their attitudes and traditions (Hofstede, 2003). Accordingly, some researchers did not report always significant impacts of TL characteristics in various cultures (Table 1).

Following these further, Hofstede (2009) noted that in the cultures where people have high power distance, employees are group oriented and need to be told for every step to proceed further. As noted by Simith et al., (2002) those people like formal rules and procedures whereas TL is less productive.

Besides, by the higher uncertainty avoidant cultures, people are less tended to be innovative or future oriented (Jung et al., 1995). It has been also noted that in these cultures transactional leadership is more productive to apply rules and procedures, where people have less self-efficacy. On the other hand, TL might be more effective in lower uncertainty avoidant cultures whereas TL stimulate and support employee innovative behaviours (Jung et al., 1995).

Consequently, collectivist cultures are more homogeneous and share responsibility in groups, they are tended to follow rules and trust their leader (House et al. 1997). Therefore, in these cultures' leaders should define tasks based on the group preferences and use team performance appraisal programs and rewards to increase motivation and performance (Crede et al. 2019).

\section{References}

Abdulla, N., Wrya, H., \& Durmaz, O. (2020). Green Product Perception in Kurdistan Region of Iraq. Black Sea Journal of Management and Marketing, 1(1), 1-15. 
AL-Abrrow, H. A. (2018). The effect of perceived organisational politics on organisational silence through organisational cynicism: Moderator role of perceived support. Journal of Management \& Organization, 1-20.

Al-Abrrow, H. A. W. (2014). Transformational leadership and organisational performance in the public healthcare sector: The role of organisational learning and intellectual capital. Irish Journal of Management, 33(1), 27.

Ali, S. H. K., Khan, N. S., \& Yildiz, Y. (2020). Leadership effects on CSR employee, media, customer, and NGOs. Management and Eco-nomics Research Journal, 6.

Altun, M. (2017). The effects of teacher commitment on student achievement: A case study in Iraq. International Journal of Academic Research in Business and Social Sciences, 7(11), 417-426.

Anwar, K., \& Balcioglu, H. (2016). The relationship between transformational leadership characteristics and effectiveness: A case study of construction companies in Erbil. International Journal of Science Technology and Management, 5(2), 250-256.

Bass, B. M. (1985). Leadership: Good, better, best. Organizational Dynamics, 13(3), 26-40.

Bass, B. M. (2002). Cognitive, social, and emotional intelligence of transformational leaders. In Kravisde Roulet Leadership Conference, 9th, Apr 1999, Claremont McKenna Coll, Claremont, CA, US. Lawrence Erlbaum Associates Publishers.

Bass, B. M., \& Avolio, B. J. (1994). Transformational leadership and organizational culture. The International Journal of Public Administration, 17(3-4), 541-554.

Bayram, H., \& Dinç, S. (2015). Role of transformational leadership on employee's job satisfaction: The case of private universities in Bosnia and Herzegovina. European Researcher. Series A, (4), 270-281.

Boerner, S., Eisenbeiss, S. A., \& Griesser, D. (2007). Follower behavior and organizational performance: The impact of transformational leaders. Journal of Leadership \& Organizational Studies, 13(3), 15-26.

Brewer, P., \& Venaik, S. (2011). Individualism-collectivism in Hofstede and GLOBE. Journal of International Business Studies, 42(3), 436-445.

Budur, T. (2018). The impact of Al-Ghazali's virtues on organizational commitment and performance: A case Study at private education institutions in Kurdistan Region of Iraq. Icabep, Erbil-Iraq, 2, $\mathrm{p} 21$.

Budur, T., \& Demir, A. (2019a). Leadership effects on employee perception about CSR in Kurdistan Region of Iraq. International Journal of Social Sciences \& Educational Studies, 6(1). 142-154.

Budur, T., \& Demir, A. (2019b). Leadership perceptions based on gender, experience, and education. International Journal of Social Sciences \& Educational Studies, 6(1), 142-154.

Budur, T., \& Poturak, M. (2020). Transformational leadership and its impact on customer satisfaction. Measuring mediating effects of organizational citizenship behaviors. Middle East Journal of Management.

Budur, T., \& Poturak, M. (2021). Employee performance and customer loyalty: Mediation effect of customer satisfaction. Middle East Journal of Management.

Burns, J.M. (1978). Leadership. New York: Harper and Row.

Craig, C. S., \& Douglas, S. P. (2011). Assessing cross-cultural marketing theory and research: A commentary essay. Journal of Business Research, 64(6), 625-627.

Crede, M., Jong, J., \& Harms, P. (2019). The generalizability of transformational leadership across cultures: A meta-analysis. Journal of Managerial Psychology.

Demir, A., \& Budur, T. (2019). Roles of leadership styles in corporate social responsibility to nongovernmental organizations (NGOs). International Journal of Social Sciences \& Educational Studies, 5(4), 174-183.

Demir, A., \& Bulut, I. (2018). A new model for respected meetings. Procedia Computer Science, 126, $1637-1655$. 
Dionne, S. D., Yammarino, F. J., Atwater, L. E., \& Spangler, W. D. (2004). Transformational leadership and team performance. Journal of Organizational Change Management, 17(2), 177-193.

Ergeneli, A., Gohar, R., \& Temirbekova, Z. (2007). Transformational leadership: Its relationship to culture value dimensions. International Journal of Intercultural Relations, 31(6), 703-724.

Faeq, M. (2020). Performance Evaluation Criteria Development Process for Academic Staff at Universities. Black Sea Journal of Management and Marketing, 1(1), 59-70.

Hama, H. H. (2015). Politicization of Kurdish security in Iraq since 2003. Jadavpur Journal of International Relations, 19(2), 137-158.

Hama, H. H. (2019). The consequences of the fragmented military in Iraqi Kurdistan. British Journal of Middle Eastern Studies, 1-16.

Hassan, S. (2015a). The Influence of National Culture on International Marketing \& Consumer Behavior in Iraqi Kurdistan, Using Hofstede's Model at Individual Level. British Journal of Marketing Studies, 3(8), 50-78.

Hassan, S. (2015b). Change in scores of Hofstede's Cultural Dimensions in Iraq by using Individual Level of Measures, a case study of Iraqi Kurds. Change, 7(9).

Hofstede, G. (1980). Understanding cultural differences. Sage, Beverly Hills, GA. Business, Management and Education, 20(2), 10.

Hofstede, G. (1986). Cultural differences in teaching and learning. International Journal of Intercultural Relations, 10(3), 301-320.

Hofstede, G. (1998). Attitudes, values, and organizational culture: Disentangling the concepts. Organization Studies, 19(3), 477-493.

Hofstede, G. (2003). Cultural dimensions. Retrieved from www. Geert Hofstede. com.

Hofstede, G. (2009). Geert Hofstede cultural dimensions.

Hofstede, G. (2011). Dimensionalizing cultures: The Hofstede model in context. Online Readings in Psychology and Culture, 2(1), 8.

Hofstede, G., \& Bond, M. H. (1984). Hofstede's culture dimensions: An independent validation using Rokeach's value survey. Journal of Cross-Cultural Psychology, 15(4), 417-433.

Hofstede, G., \& Fink, G. (2007). Culture: organizations, personalities, and nations. Gerhard Fink interviews Geert Hofstede. European Journal of International Management, 1(1-2), 14-22.

House, R. J., Wright, N. S., \& Aditya, R. N. (1997). Cross-cultural research on organizational leadership: A critical analysis and a proposed theory.

Howell, J. M., \& Avolio, B. J. (1993). Transformational leadership, transactional leadership, locus of control, and support for innovation: Key predictors of consolidated-business-unit performance. Journal of Applied Psychology, 78(6), 891.

Jung, D. I., Bass, B. M., \& Sosik, J. J. (1995). Bridging leadership and culture: A theoretical consideration of transformational leadership and collectivistic cultures. Journal of Leadership Studies, 2(4), 3-18.

Kamal, T., \& Shawkat, S. (2020). The impact of dynamic capabilities on knowledge management in Kurdistan Region of Iraq. Black Sea Journal of Management and Marketing, 1(1), 41-48.

Kanwal, F., Rathore, K., \& Qaisar, A. (2019). Relationship of benevolent leadership and organizational citizenship behavior: Interactional effect of perceived organizational support and perceived organizational politics. Pakistan Journal of Commerce and Social Sciences (PJCSS), 13(2), 283-310.

Koran, E., \& Koran, S. (2017). Principals' leadership styles and strategies employed to motivate teachers in Ronaki Hawler educational institutions, Erbil, Iraq. International Journal of Social Sciences \& Educational Studies, 4(3), 146-159.

Lenartowicz, T., \& Roth, K. (1999). A framework for culture assessment. Journal of International Business Studies, 30(4), 781-798. 
Linge, T. K., \& Sikalieh, D. (2019). Influence of idealized influence on employee job performance in the insurance industry in Kenya. International Journal of Research in Business and Social Science (2147-4478), 8(5), 266-273.

Mead, R., \& Jones, C. J. (2017). Cross- Cultural Communication. The Blackwell Handbook of CrossCultural Management, 283-291.

Mohammed, S. S., Suleyman, C., \& Taylan, B. (2020). Burnout Determinants and Consequences Among University Lecturers. Amazonia Investiga, 9(27), 13-24.

Mujkić, A., Šehić, D., Rahimić, Z., \& Jusić, J. (2014). Transformational leadership and employee satisfaction. Ekonomski Vjesnik: Review of Contemporary Entrepreneurship, Business, and Economic Issues, 27(2), 259-270.

Rarick, C., Winter, G., Barczyk, C., \& Merkt, E. (2014). Iraqi and Kurdish cultural values in the semiautonomous state of Kurdistan. Global Journal of Management and Business Research.

Schein, E. H. (1986). What you need to know about organizational culture. Training \& Development Journal.

Smith, P. B., Peterson, M. F., \& Schwartz, S. H. (2002). Cultural values, sources of guidance, and their relevance to managerial behavior: A 47-nation study. Journal of Cross-cultural Psychology, 33(2), 188-208.

Soares, A. M., Farhangmehr, M., \& Shoham, A. (2007). Hofstede's dimensions of culture in international marketing studies. Journal of Business Research, 60(3), 277-284.

Sojka, J., \& Tansuhaj, P. S. (1995). Cross-cultural consumer research: A twenty-year review. ACR North American Advances.

Tajeddini, K. (2010). Effect of customer orientation and entrepreneurial orientation on innovativeness: Evidence from the hotel industry in Switzerland. Tourism Management, 31(2), 221-231.

Tajeddini, K., \& Mueller, S. L. (2012). Corporate entrepreneurship in Switzerland: Evidence from a case study of Swiss watch manufacturers. International Entrepreneurship and Management Journal, 8(3), 355-372.

Top, C., Abdullah, B. M. S., \& Faraj, A. H. M. (2020). Transformational leadership impact on employees performance. Eurasian Journal of Management \& Social Sciences. 1(1), 49-59

Torlak, N. G., \& Kuzey, C. (2019). Leadership, job satisfaction and performance links in private education institutes of Pakistan. International Journal of Productivity and Performance Management.

Welch, M., \& Jackson, P. R. (2007). Rethinking internal communication: a stakeholder approach. Corporate Communications: An International Journal, 12(2), 177-198.

Wennekers, S., Thurik, R., van Stel, A., \& Noorderhaven, N. (2007). Uncertainty avoidance and the rate of business ownership across 21 OECD countries, 1976-2004. Journal of Evolutionary Economics, 17(2), 133-160.

Yildiz, Y., \& Amin, H. H. H. (2020). Impact of organizational citizenship behavior on customer satisfaction. Eurasian Journal of Management \& Social Sciences. 1(1), 17-35

Zaim, H., Demir, A., \& Budur, T. (2020). Ethical leadership, effectiveness and team performance: An islamic perspective. Middle East Journal of Management.

Zardasht, P., Omed, S., \& Taha, S. (2020). Importance of HRM policies on employee job satisfaction. Black Sea Journal of Management and Marketing, 1(1), 49-57. 